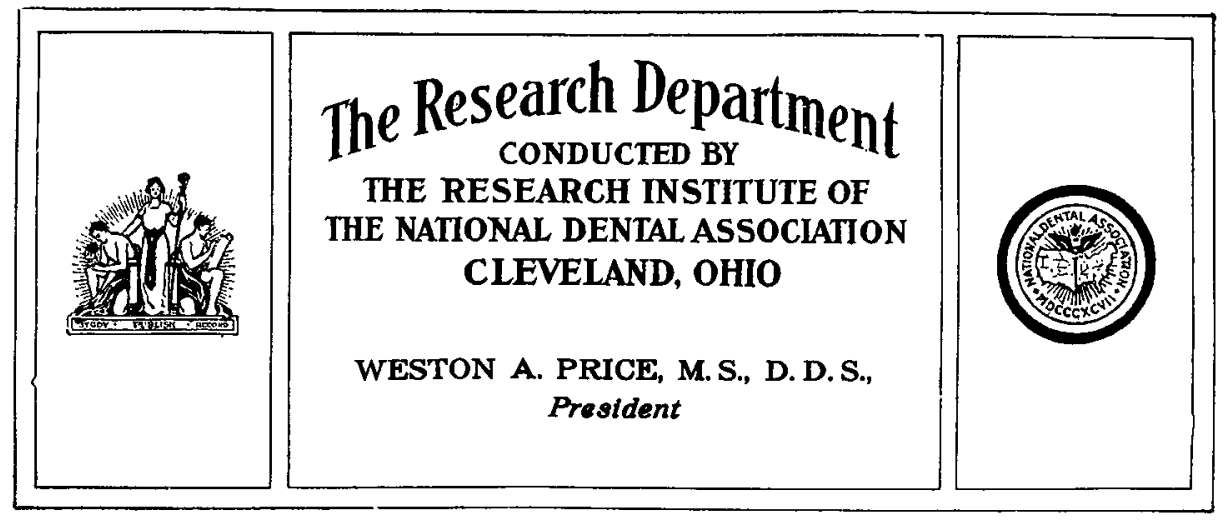

\title{
A MEMORIAL HOUR TO THE LATE DR. JOHN R. CALLAHAN.
}

\section{A BRIEF REVIEW OF HIS PROFESSIONAL ACTIVITIES.}

\author{
By T. Irving Way, D. D.S., Cincinnati, Ohio.
}

(Read before the National Dental Association at Its Twenty-second Annual Session, Chicago, Ill., August 5-9, 1918.)

I $\mathrm{T}$ IS indeed a privilege to join with you at this hour in paying tribute to, and in this small way honoring that man who gave so freely of his time and ability, whose constant endeavor was to make for better service and a higher standard of the profession. Dr. Callahan's dental activities began early in life. His father, a physician and dentist, was associated with Dr. John Ellis in the practice of dentistry in Hillsboro, Ohio, in the early seventies. Under the direction of these two men he began the study of dentistry. He later entered The Philadelphia Dental College and was graduated from that institution February 27 th, 1877 , receiving the degree of Doctor of Dental Surgery.

After his graduation he began the practice of his profession in San Fran- cisco, Cal., as the associate of his classmate, Dr. Washington G. Winter. Two years later he returned to Hillsboro and continued the practice of dentistry in that village until 1890 when he removed to Cincinnati, Ohio, where he succeeded to the practice of Dr. C. R. Taft (brother of the late Johnathan Taft.)

To him the practice of dentistry was a tremendous responsibility, whether in the village or city, thruout his entire career he was an earnest advocate of the "Dignity of Service." Coupled with his unusual ability he established and maintained a practice of the most desirable character.

One of the highest testimonials to a professional man's worth is that of an appreciative Clientele whose loyalty extends over a long period of years. This 
was accorded Dr. Callahan in full measure.

The following tribute from a friend and patient expresses the feelings of the many he served so faithfully and well.

"The mind and temperament of Dr. Callahan seem to have been rarely well suited to his chosen task of securing for his fellow-men all those services of a science which his patient study had mastered. Lucid and inflexible in pursuit of truth, yet was his mind tempered by a kindly sympathy that had almost a women's tenderness in the offering of that helpful service for which he was so richly equipped. To patients he endeared himself furthermore thru a wholesome interest in their occupations. With him in confidence the young, ambitious, mechanical engineer talked over his plans. The poor little girl in the hospital, whose treatment had been severe and painful chatted with him in enjoyment of her "nice new dress." The sensitive woman, with nerves too high-strung he quieted with a word, firmly but kindly spoken. It was all very definite and clear, whether the professional advice and treatment or the friend's kindly interest. There was a subtle delicacy in his strength which anyone could see who watched the very expressive movements of the perfectly controlled fingers of his remarkable hands, - in themselves highly characteristic of the man. While listening to him talk, my eyes were wont to watch his hands, so expressive were they of the spirit of his speech. As I know it did to many others, his friendship meant very much to me in hours of pleasant relaxation and in times of perplexity and trial, and I shall always treasure the recollection of it."

Dr. Callahan's professional activities were not confined to the daily routine of his office. To have a part in the growth and development of dentistry was as much a part of his life work as the practice of his profession. He was active in
National, State and local societies. Entering practice in Ohio in 1879-he became a member of the State Society in that year. Taking a lively interest in its affairs, in 1884 he was elected Secretary, which office he held thruout the succeeding years, up to and including 1890-during which time he devoted much thought and energy to the advancement of the Society, and in 1892 was its President and from 1894 to 1918 inclusive was a member of the Board of Directors. Early in the eighties he joined The Mississippi Valley Dental Association which at that time was one of the leading Dental Societies of the middle west, being active in its affairs. He was president in 1889.

For many years a member of the $\mathrm{Na}$ tional Dental Association, you are familiar with his share in its development. Since its reorganization he was continuously a member of the House of Delegates.

As we review his activities in the Cincinnati Dental Society it is difficult to express the real value of the man. Ambitious for its advancement, he gave generously of his time and talent to the furthering of its interests.

President of the Society in 1906-1907 he succeeded himself the following year. Largely thru his inspiration and influence nowhere do we find a local organization where harmony prevails and loyalty amongst the membership is greater than in his home society.

As we turn from the brief review of his life in practice and society work to contemplate his contribution to the literature and science of dentistry, it is with appreciation of his inspiration, patient endeavor and industry.

In 1888 he prepared his first paper. The Conservation of the Dental Pulp, which he read before the Mississippi Valley Association that year.

Quoting from his remarks at the dinner given in his honor in Cincinnati, 
June 12th, 1917: "My first encouragement to undertake Research Work came from Dr. Atkinson of New York, who was present at the meeting of the Mississippi Valley Association, many years ago. I read on that occasion the first paper I ever had prepared. When I got thru reading $I$ was nervous and excited. I wish the floor would open and let me drop thru. Dr. Atkinson whispered to me "My boy you read well, you keep on writing papers and some day you will write something worth while." That Dr. Atkinson's words were prophetic is evidenced by the results of Dr. Callahan's efforts.

To better equip himself for research work after locating in Cincinnati he took up the study of medicine in the Miami Medical College of that city and pursued his studies to within two months of graduation. $\mathrm{He}$ stated that having acquired the knowledge to aid in his work, not caring for a degree in Medicine he did not complete the course.

During this time, he, together with Drs. M. H. Fletcher and O. N. Heisie formed a study class, meeting in each others offices in the evenings and Saturday afternoons, which arrangement was continued for several years. Devoting his energies to the self imposed task in one problem in experimental research. In 1893 he gave one of his most valuable contributions to dentistry, in a paper read before the Ohio State Society, "Sulphuric Acid for Opening Rootcanals." He established a method of rational treatment and preparation of canals in pulpless teeth.

In recognition of this valuable contribution to dental science, he was accorded honor both in this country and abroad.

Several years later, 1914.-A paper, "Rosin Solution in Root-canals," read before the Rehwinkle Dental Society, amplified by subsequent papers gave the results of extensive research extending over several years proved the value of this method, which is almost universally used today.

Thruout the years following the presentation of his first paper his discussions of dental problems were numerous and valuable. Recognized as an authority, he was eagerly sought as essayist and clinician by societies thruout the country. Not possible to present a list of his contributions at this time. It is planned that later his complete writings, compiled under the direction of the $\mathrm{Na}$ tional Research Institute, will be available for the profession.

After years of study and research, on the establishing of the National Dental Research Institute, he brought to it a trained mind and hands and much valuable aid. February 23rd, 1916, he was appointed member of the Directing Medical Staff of the Cincinnati General Hospital. Director of Dental Department of the General Hospital and TubercuIosis Sanitarium and thru his influence more cordial relations between the Dental and Medical professions in Cincinnati was established. With increased facilities in the laboratories and clinics of the hospital, he devoted much of his time to research work and became so deeply engrossed that he gave little thought to his individual interests, rather hoping that he might solve the problems that so interested him while it was yet time. He was for many years an active member of the Cincinnati Research Society. Last year he realized his desires in seeing the Cincinnati Dental Research and Study Club established, in which he was the leading spirit and director of research study.

In recognition of the scientific contributions which he so freely gave to the dental profession, in May, 1917, the New York Dental Society conferred on 
him the Jarvie Fellowship Medal, one of the highest honors in dentistry in America.

The professional life of John Ross Callahan was a success. Rich in attainment, rich in the respect and apprecia- tion of a noble profession, rich in the loyalty and love of his friends and colleagues. . After forty-one years of service his activities have ceased and this quiet, unassuming man has passed to his reward.

\title{
AN ESTIMATE OF HIS PERSONALITY.
}

\author{
By Thomas P. Hinman, D. D.S., Atlanta, Ga.
}

\begin{abstract}
(Read before the National Dental Association at Its Twenty-second Annual Session, Chicago, Ill., August 5-9, 1918.)
\end{abstract}

$T^{\mathrm{T}}$ T IS given to few men to be so greatly beloved as was our departed friend, John Callahan. His friends knew him as "Honest John." No greater tribute could be paid a man than that of honesty-honest first with himself, then with the world. As the old Polonius said to Laertes, his son,

"This, above all, to thine own self be true And it must follow as the night to day

Thou canst not then be false to any man."

'There was never a man truer to his friends or more generous to his enemies. In all my fellowship with him, I never heard him speak unkindly of anyone. $\mathrm{He}$ always saw the good in everyone and it always overshadowed the fault.

I well remember the last time he was in Atlanta. $\mathrm{He}$ brought me a set of slides of root end dissections which he had made for me. Handing them to me with a smile on his face, he said, "Tom, there are only two sets of the slides in the world and one of them is yours." This is a small illustration of his constant thought for the comfort and happiness of others. His greatest joy was to give of himself and his precious time to bring pleasure to his friends, never counting the cost.
He was not a rich man, as the world counts riches but in noble qualities, truth, honesty and charity, his wealth had no bounds. Truly he laid up for himself riches that cannot fade away; treasures that "neither moth nor rust corrupteth."

John Callahan was a searcher after truth not for his own benefit but for the good of humanity. I regret to think that his useful life was taken sooner than seemed fitting because of his incessant labors on research problems, labors which indeed have brought most gratifying results in the enlightenment of one of our most serious problems. If he had been content to use his knowledge for personal gain, he could have lived in ease and comfort. But no! His desire was to work and give.

His chief charm was his simplicity. Never given to pedantry, he conveyed his thoughts so simply that "the wayfaring man, tho a fool, could not err therein." Loyal to his belief, but never obtrusive, his opinions were respected far beyond the boundaries of his personal following.

It was ever his delight to get a few friends together after a dental meeting 